Egyptian Journal of Aquatic Biology \& Fisheries

Zoology Department, Faculty of Science,

Ain Shams University, Cairo, Egypt.

ISSN $1110-6131$

Vol. 25(1): 525 - 540 (2021)

www.ejabf.journals.ekb.eg

\title{
Impact of the photosensitizers copper and magnesium chorophyllin on biological and biochemical parameters of Bulinus truncatus snail
}

\section{Hebat-Allah A. S. Dokmak ${ }^{1 *}$, Mohamed A. EL-Emam ${ }^{1}$, Hanan S. Mossalem ${ }^{1}$, Tarek A. EL-Tayeb ${ }^{3}$ and, Magdy T. Khalil ${ }^{2}$.}

\author{
${ }^{1}$ Medical Malacology Department, Theodor Bilharz Research Institute, Egypt. \\ ${ }^{2}$ Faculty of Science, Ain Shams University, Cairo, Egypt. \\ ${ }^{3}$ National Institute for Laser Enhanced Science (NILES), Egypt. \\ *Corresponding author: hebas80@yahoo.com
}

\section{ARTICLE INFO}

Article History:

Received: Dec. 30, 2020

Accepted: Jan.27, 2021

Online: Feb. 5, 2021

\section{Keywords:}

Bulinus truncatus, copper chlorophyllin, magnesium chlorophyllin photosensitizers, biochemical parameters.

\begin{abstract}
Bulinus truncatus snail is the intermediate host of Schistosoma haematobium, which causes serious damage to the urinary system of infected patients. To control it in its rapid interruption and/or elimination of the disease transmission would be efficient. Copper chlorophyllin $(\mathrm{Cu}-\mathrm{chl})$ and magnesium chlorophyllin (Mg-chl); two photosensitizers used in several biological applications, were bio-assayed against $B$. truncatus snails. $\mathrm{Mg}$-chl proved to be more toxic to the snails than $\mathrm{Cu}$-chl; their $\mathrm{LC}_{90}$ values were 516.7 and $668.9 \mathrm{ppm}$, respectively. The sub lethal concentrations of each photosensitizer significantly suppressed the fecundity $(\mathrm{Mx})$ and reproductive rate $\left(R_{0}\right)$ of treated snails, which could be partially attributed to the recorded disturbances in their biochemical parameters. The reduction rates of $\mathrm{R}_{0}$ for snails treated with $\mathrm{LC}_{25} \mathrm{Mg}$-chl and $\mathrm{Cu}$-chl were $83.5 \%$ and $50.8 \%$, respectively. Moreover, these photosensitizers exerted marked histological changes in the hermaphrodite gland of treated snails where spermatogonia and oogonia in the gland acini were degenerated, while the connective tissue was disintegrated. Both $\mathrm{Mg}$-chl and $\mathrm{Cu}-\mathrm{chl}$ exhibited toxic effect on B. truncatus snail and interfered with the biological parameters of it that could negatively interrupt the transmission of $S$. haemeatobium. Therefore, both chemicals could be considered in the control program of this parasite being cheap and environmentally safe.
\end{abstract}

\section{INTRODUCTION}

Schistosomiasis is one of the major communicable diseases with socioecomomic and health importance in the developing world (Steinmanr et al, 2006). There are multiple parameters affecting schistosomiasis transmission, among which is the snail intermediate host (Abdel-Hamid and Meckawey, 2014). Snails control by molluscicides could be one of the methods of choice for schistosomiasis control (Rizk et al, 2012). Molluscicides of natural origin have several advantages over the synthetic compounds (Perrett and Whitfield, 1996). In 2004, Ibrahim et al demonstrated a great histological damage in the ovotestis of Biomphalaria alexandrina snails post exposure to the plants Panicum repens and Solanum nigrum 
that resulted in ceasing snails' oviposition after 4 weeks of exposure. Moreover, Bakry (2009) added that methanol extract of the plants Euphorbia splendens and Agave stylosa negatively deteriorated the biological and physiological activities of $B$. alexandrina snails. Similarly, Mossalem et al (2013) stated that the antimalarial drug artemether has molluscicidal effect against $B$. alexandrina snails. Recently, in semifield and field trials in Egypt, the plant molluscicide Luowei/TDS 4\% proved to be a potent molluscicide against B. alexandrina and Bulinus truncatus snails (El-Emam et $a l, 2020)$. Most of the Photosensitizers are used nowadays to control noxious insects and some parasites. Photosensitization is a novel treatment involving the administration of a photoactive compound that accumulates in certain cells of the exposed organism, and if followed by the exposure to visible light, these cells will be killed (Luksiene, 2005).Chlorophyllin, the chlorophyll derivative, is among the recently promising photosensitizers used in this field.

Sodium/ Copper derivative is the most common form of chlorophyllin used as a food additive. The photodynamic process using chlorophyll and its derivatives have been promising agents in the pest control (Erzinger et al, 2011). Thus, field investigations using chlorophyll derivatives were carried out to control malaria, filaria and dengue fever vectors in infested epidemic swamps in Uganda, Ethiopia and Sudan (Abdel-kader and EL-Tayeb, 2012). In these investigations chlorophyll derivatives were added to the swamps infested with mosquito larvae Anopheles gambiae, thereafter the accumulated photoactive compound (photosensitizer) inside the larva body induced upon sunlight exposure an oxidation stress that resulted in their death. Additionally, Awad et al (2008) observed that the photosensitizer hematoporphyrin IX was lethal to mosquito larvae Culex pipiens after 5 days of exposure to $1 \times 10^{-4} \mathrm{M}$, and attributed this to the damage of organelles in the cells of treated larvae as a result of the high oxidative stress caused by the photosensitize effect.

Thus, photosensitizers and light (photosensitization) could help in developing novel and environmentally safe effective method for controlling the medically important snails. Therefore, molluscicidal activities of sodium copper chlorophyllin and sodium magnesium chlorophyllin were evaluated against biological and biochemical parameters of Bulinus truncatus snails.

\section{MATERIALS AND METHODS}

\section{Copper chlorophyllin and magnesium chlorophyllin:}

The photosensitizers' sodium/copper chlorophyllin (Cu-chl) and sodium/ magnesium chlorophyllin (Mg-chl) were kindly provided by prof. Tarek EL-Tayeb, National Institute for Laser Enhanced Science (NILES), Cairo University, Egypt.

\section{Snails}

Laboratory-bred $B$. truncatus snails used in the present study were from a colony maintained at the Medical Malacology Department, Theodor Bilharz Research Institute (TBRI), Imbaba, Giza, Egypt. They were maintained in aquaria containing de- chlorinated water $\left(24 \pm 1^{\circ} \mathrm{C}\right)$ and fed oven-dried lettuce leaves. Water was changed once a week and dead snails were removed. 


\section{Bioassay tests}

A stock solution of $1000 \mathrm{ppm}$ from each of $\mathrm{Cu}-\mathrm{chl}$ and $\mathrm{Mg}$-chl was prepared, and dilutions were performed for determining $\mathrm{LC}_{10}, \mathrm{LC}_{25}, \mathrm{LC}_{50}$ and $\mathrm{IC}_{90}$ against Bulinus truncatus snails post incubation with these compounds and exposed to light. Therefore, those snails were incubated in the dark with the concentrations of $450,500,550,600,650$ and $700 \mathrm{mg} / \mathrm{L}$ of copper chlorophyllin for 6 hours and with $250,300,350,400,500$, and $550 \mathrm{mg} / \mathrm{L}$ of magnesium chlorophyllin for $6 \mathrm{~h}$ (Ragheb et $a l, 2013$ ). After that they were exposed to light (desk lamp, $100 \mathrm{w} / 15 \mathrm{~cm}$ height) for a 3 hours period.

Afterwards, snails were thoroughly washed and transferred to a clean dechlorinated water to recover for 24 hours. For each concentration, 3 replicates were used, each of which 10 snails $(6-8 \mathrm{~mm}) / \mathrm{L}$ were utilized. Mortality of snails was recorded (WHO, 1993) and analyzed to obtain the lethal concentration values by probit analysis software (WHO, 1965 \& Finney, 1970). For control groups, light and dark controls were allowed to run along with the test samples. In light control group, the tested snails were maintained in clean de-chlorinated water under the same experimental conditions. While the dark control involved incubation of the snails with the highest tested concentration of $\mathrm{Cu}$-chl or $\mathrm{Mg}$-chl in the dark under the same experimental conditions without light exposure.

\section{Effect on snail's fecundity}

Three replicates of $B$. truncatus $(6-8 \mathrm{~mm})$, each containing 10 snails/L, were incubated in the dark with $\mathrm{LC}_{10}$ and $\mathrm{LC}_{25}$ of $\mathrm{Cu}$-chl and $\mathrm{Mg}$-chl once merely at the beginning of the experiment. The incubation period was 6 hours for $\mathrm{Cu}-\mathrm{chl}$ and $\mathrm{Mg}$ chl (optimum periods for snails to survive incubation) followed by exposure to light for 3 hours (desk lamp, $100 \mathrm{w} / 15 \mathrm{~cm}$ height) (Ragheb et al. 2013). Then, the snails were transferred to clean de-chlorinated water for recovery and observation during the following eight consecutive weeks under laboratory conditions (ceiling light, $25 \pm 1^{\circ} \mathrm{C}$ ). The dark and light control groups were run parallel to the test groups. The light control snails were kept in clean de-chlorinated water without any treatment, and exposed to light followed by eight weeks of recovery. The dark control snails, incubated with $\mathrm{Cu}$-chl and $\mathrm{Mg}$-chl without light exposure, were transferred to clean de-chlorinated water for recovery. The survivorship of snails (Lx) and the number of laid eggs/snails (Mx) were recorded weekly; the reproductive rate $\left(\mathrm{R}_{0}\right)$ was calculated at the end of the experiment. Throughout the experimental period the snails were fed oven-dried lettuce leaves and the aquaria were provided with pieces of foam sheets for egg deposition, meanwhile, water was changed weekly.

\section{Effect on biochemical parameters of snails}

The soft tissues of the surviving snails in the treated and control (light and dark) groups were removed from the shells and homogenized $(1 \mathrm{~g} / 2 \mathrm{~mL}$ dechlorinated water) using UP $200 \mathrm{H}$ ultrasonic processor, whereas the suspensions were centrifuged at $4,000 \mathrm{rpm}$ for $45 \mathrm{~min}$ at $25 \pm 1{ }^{\circ} \mathrm{C}$. The pellets were discarded while the supernatant was subjected to estimate the activities of transaminase's enzymes (ALT 
and AST) using the Reitman and Frankel (1957) technique, on the other hand, alkaline phosphatase (ALP) was performed according to Bessey et al (1946), while total protein was determined according to the method of Doumas (1975). In addition, Albumin was determined according to Gustafsson (1976). Calculation of globulin was determined by subtracting the amount of albumin from the total protein.

\section{Effect on histological features of the hermaphrodite gland}

The snails were treated with $\mathrm{LC}_{50} \& \mathrm{LC}_{90}$ of $\mathrm{Cu}$-chl and $\mathrm{Mg}$-chl as mentioned before. Light and dark control groups were simultaneously carried out. Three replicates (10 snails/ L for each) were used for both control and the tested groups. Thereafter, the snail's hermaphrodite gland was dissected out of their shells and were fixed using Bouin's fixative, then embedded in wax blocks, sectioned $(5-8 \mu \mathrm{m})$, and stained with delafied haematoxyline and eosin (EL-Nahas and EL-Deeb, 2007). Similarly, sections of control snails' hermaphrodite glands were prepared.

\section{Statistical analyses}

Statistical analyses were run on IBM compatible PC using SPSS for windows statistical package (SPSS, 2006). Lethal concentrations were calculated using probit analysis software. The mortality rates of experimental groups were compared using Pearson's Chi-square test. Values of biochemical parameters were expressed as mean \pm SD. Student's t-test was applied to locate significant changes between control and treated groups (Sokal and Rohlf, 1995).

\section{RESULTS}

The molluscicidal activity of $\mathrm{Cu}-\mathrm{chl}$ and $\mathrm{Mg}$-chl against Bulinus truncatus snails was concentration dependent (Table 1). Notably, $\mathrm{Mg}$-chl was more toxic to B. truncatus snails than $\mathrm{Cu}-\mathrm{chl}$. Their $\mathrm{LC}_{90}$ values were 516.7 and $668.9 \mathrm{ppm}$, respectively after 6 hours of dark incubation and 3 hours exposure to light (desk lamp, $100 \mathrm{w} / 15 \mathrm{~cm}$ heights). The slope values indicated that the lethal concentration probability lines (LCP) of these compounds were steep, and their heterogeneity factor was less than 1.0, demonstrating the log-concentration-probit lines to be within the $95 \%$ confidence limits, and thus the model fitted the observed data (Kavita et al., 2017).

Table (1): Molluscicidal activity of copper chlorophyllin (Cu-chl) and magnesium chlorophyllin (Mg-chl) against Bulinus truncatus snails.

\begin{tabular}{ccccccc}
\hline Compound & $\begin{array}{c}\mathbf{L C}_{\mathbf{1 0}} \\
(\mathbf{p p m})\end{array}$ & $\begin{array}{c}\mathbf{L C}_{\mathbf{2 5}} \\
(\mathbf{p p m})\end{array}$ & $\begin{array}{c}\mathbf{L C}_{\mathbf{5 0}} \\
(\mathbf{p p m})\end{array}$ & $\begin{array}{c}\text { Confidence } \\
\text { limits of } \mathbf{L C}_{\mathbf{5 0}} \\
(\mathbf{p p m})\end{array}$ & $\begin{array}{c}\mathbf{L C}_{\mathbf{9 0}} \\
(\mathbf{p p m})\end{array}$ & Slope \\
\hline $\begin{array}{c}\text { Copper } \\
\text { chlorophyllin } \\
\begin{array}{c}\text { Magnesium } \\
\text { chlorophyllin }\end{array}\end{array}$ & 473.9 & 520.1 & 571.4 & $492.2-623.7$ & 668.9 & $\mathbf{1 . 1 5}$ \\
\hline
\end{tabular}

Regarding the egg-laying capacity of $B$. truncatus snails treated with $\mathrm{Cu}-\mathrm{chl}$ and $\mathrm{Mg}$-chl, the data in Tables $2 \& 3$ revealed a gradual decrease in their survivorship (Lx) during the experimental period ( 8 weeks). The $\mathrm{Lx}$ at the $8^{\text {th }}$ week was $0.4(40 \%)$ 
and $0.2(20 \%)$ for snails treated with $\mathrm{LC}_{25}$ of $\mathrm{Cu}-\mathrm{chl}$ and $\mathrm{Mg}$-chl, respectively, compared to 0.7 (70\%) for light control group.

Table (2): Survivorship and fecundity of Bulinus truncatus snails incubated with copper chlorophyllin ( $\mathrm{Cu}$-chl) for 6 hours then exposed to light for 3 hours.

\begin{tabular}{|c|c|c|c|c|c|c|c|c|c|c|c|c|c|c|c|}
\hline \multirow{2}{*}{$\begin{array}{l}\text { Observatio } \\
\text { Period } \\
\text { (week) }\end{array}$} & \multicolumn{3}{|c|}{ Light control } & \multicolumn{3}{|c|}{$\begin{array}{l}\text { Cu-chl } \mathrm{LC}_{10}(\mathrm{ppm}) \\
\text { dark control }\end{array}$} & \multicolumn{3}{|c|}{ Cu-chl LC $_{10}(\mathrm{ppm})$} & \multicolumn{3}{|c|}{$\begin{array}{l}\mathrm{Cu} \text {-chl } \mathrm{LC}_{25}(\mathrm{ppm}) \\
\text { dark control }\end{array}$} & \multicolumn{3}{|c|}{ Cu-chl LC ${ }_{25}(\mathrm{ppm})$} \\
\hline & $\mathrm{Lx}$ & Mx & LxMx & $\mathrm{Lx}$ & $\mathrm{Mx}$ & LxMx & Lx & $\mathrm{Mx}$ & LxMx & $\mathrm{Lx}$ & Mx & LxMx & $\mathrm{Lx}$ & $\mathrm{Mx}$ & LxMx \\
\hline 0 & 1.0 & 1.4 & 1.4 & 1.0 & 1.4 & 1.4 & 1.0 & 1.4 & 1.4 & 1.0 & 1.4 & 1.4 & 1.0 & 1.4 & 1.4 \\
\hline 1 & 1.0 & 3.84 & 3.84 & 0.9 & 1.1 & 0.99 & 1.0 & 0.0 & 0.0 & 1.0 & 1.3 & 1.3 & 0.7 & 2.6 & 1.82 \\
\hline 2 & 0.9 & 1.20 & 0.96 & 0.9 & 0.0 & 0.0 & 0.8 & 0.0 & 0.0 & 1.0 & 0.4 & 0.4 & 0.6 & 0.0 & 0.0 \\
\hline 3 & 0.9 & 0.44 & 0.39 & 0.8 & 0.0 & 0.0 & 0.8 & 0.0 & 0.0 & 0.8 & 0.25 & 0.2 & 0.6 & 0.0 & 0.0 \\
\hline 4 & 0.9 & 2.11 & 1.90 & 0.8 & 0.0 & 0.0 & 0.7 & 0.0 & 0.0 & 0.8 & 2.5 & 2.0 & 0.5 & 0.0 & 0.0 \\
\hline 5 & 0.9 & 2.11 & 1.90 & 0.8 & 0.4 & 0.32 & 0.7 & 0.42 & 0.29 & 0.7 & 1.03 & 0.72 & 0.4 & 1.0 & 0.4 \\
\hline 6 & 0.8 & 0.0 & 0.0 & 0.7 & 0.5 & 0.35 & 0.7 & 0.0 & 0.0 & 0.7 & 1.21 & 0.85 & 0.4 & 6.44 & 2.57 \\
\hline 7 & 0.8 & 2.0 & 1.60 & 0.7 & 1.4 & 0.98 & 0.7 & 0.5 & 0.35 & 0.7 & 1.54 & 1.08 & 0.4 & 0.0 & 0.0 \\
\hline 8 & 0.7 & 2.0 & 1.40 & 0.7 & 1.4 & 0.98 & 0.6 & 0.4 & 0.24 & 0.6 & 1.21 & 0.73 & 0.4 & 1.0 & 0.4 \\
\hline $\mathrm{R}_{0} \pm \mathrm{S} . \mathrm{D}$ & \multicolumn{3}{|c|}{$13.39 \pm 1.10$} & \multicolumn{3}{|c|}{$5.02 \pm 0.53$} & \multicolumn{3}{|c|}{$2.28 \pm 0.45$} & \multicolumn{3}{|c|}{$8.68 \pm 0.55$} & \multicolumn{3}{|c|}{$6.59 \pm 0.96$} \\
\hline \multicolumn{4}{|c|}{ Reduction (\%) of $\mathrm{R}_{0}$} & \multicolumn{3}{|c|}{62.5} & \multicolumn{3}{|c|}{83.8} & \multicolumn{3}{|c|}{35.2} & \multicolumn{3}{|c|}{50.8} \\
\hline
\end{tabular}

The fecundity $(\mathrm{Mx})$ of snails incubated with $\mathrm{Cu}-\mathrm{chl}$ and $\mathrm{Mg}$-chl followed by exposure to light was decreased compared to light control group. Thus, after 8 weeks of recovery, the $\mathrm{Mx}$ values considering snails at $\mathrm{LC}_{10}$ of $\mathrm{Cu}$-chl and $\mathrm{Mg}$-chl were 0.4 and 0.5 eggs/snails/week, respectively, compared to light control group with values of 2.0 eggs/snail/week. Moreover, the snails survived at $\mathrm{LC}_{10}$ and $\mathrm{LC}_{25}$ in each of the tested compounds ceasing egg-laying for 3 or 4 weeks during the recovery period. Similarly, dark control group in $\mathrm{LC}_{10}$ of each compound suffered from ceasing egglaying during the recovery period and thus, laid few eggs during this period.

Table (3): Survivorship and fecundity of $B$. truncatus snails incubated with magnesium chlorophyllin (Mg-chl) for 6 hours followed with exposure to light for 3 hours.

\begin{tabular}{|c|c|c|c|c|c|c|c|c|c|c|c|c|c|c|c|}
\hline \multirow[t]{2}{*}{$\begin{array}{l}\text { Observation } \\
\text { Period } \\
\text { (week) }\end{array}$} & \multicolumn{3}{|c|}{ Light control } & \multicolumn{3}{|c|}{$\begin{array}{l}\text { Mg-chl LC } \mathrm{LC}_{10}(\mathrm{ppm}) \\
\text { dark control }\end{array}$} & \multicolumn{3}{|c|}{$\begin{array}{l}\mathrm{Mg}-\operatorname{chlLC}_{10} \\
(\mathrm{ppm})\end{array}$} & \multicolumn{3}{|c|}{$\begin{array}{l}\text { Mg-chl } \\
\mathrm{LC}_{25}(\mathrm{ppm}) \text { dark } \\
\text { control }\end{array}$} & \multicolumn{3}{|c|}{$\begin{array}{l}\mathrm{Mg}-\mathrm{chlLC}_{25} \\
(\mathrm{ppm})\end{array}$} \\
\hline & Lx & $\mathrm{Mx}$ & LxMx & $\mathrm{Lx}$ & $\mathrm{Mx}$ & LxMx & $\mathrm{Lx}$ & $\mathrm{Mx}$ & LxMx & $\mathrm{Lx}$ & $\mathrm{Mx}$ & LxMx & $\mathrm{Lx}$ & Mx & LxMx \\
\hline 0 & 1.0 & 1.4 & 1.4 & 1.0 & 1.4 & 1.4 & 1.0 & 1.4 & 1.4 & 1.0 & 1.4 & 1.4 & 1.0 & 1.4 & 1.4 \\
\hline 1 & 1.0 & 3.84 & 3.84 & 0.9 & 0.0 & 0.0 & 0.9 & 0.0 & 0.0 & 0.8 & 0.0 & 0.0 & 0.7 & 0.7 & 0.49 \\
\hline 2 & 0.9 & 1.20 & 0.96 & 0.9 & 0.0 & 0.0 & 0.8 & 0.0 & 0.0 & 0.8 & 0.0 & 0.0 & 0.7 & 0.0 & 0.0 \\
\hline 3 & 0.9 & 0.44 & 0.39 & 0.8 & 0.0 & 0.0 & 0.6 & 0.0 & 0.0 & 0.7 & 0.0 & 0.0 & 0.5 & 0.0 & 0.0 \\
\hline 4 & 0.9 & 2.11 & 1.90 & 0.7 & 0.0 & 0.0 & 0.6 & 0.0 & 0.0 & 0.7 & 0.0 & 0.0 & 0.4 & 0.0 & 0.0 \\
\hline 5 & 0.9 & 2.11 & 1.90 & 0.7 & 0.0 & 0.0 & 0.5 & 0.6 & 0.3 & 0.6 & 0.8 & 048 & 0.4 & 0.5 & 0.2 \\
\hline 6 & 0.8 & 0.0 & 0.0 & 0.7 & 0.53 & 0.37 & 0.4 & 0.0 & 0.0 & 0.6 & 0.0 & 0.0 & 0.2 & 0.5 & 0.1 \\
\hline 7 & 0.8 & 2.0 & 1.60 & 0.7 & 1.42 & 0.99 & 0.4 & 0.8 & 0.32 & 0.6 & 0.6 & 0.36 & 0.2 & 0.0 & 0.0 \\
\hline 8 & 0.7 & 2.0 & 1.40 & 0.6 & 1.30 & 0.78 & 0.3 & 0.5 & 0.15 & 0.5 & 0.5 & 0.25 & 0.2 & 0.1 & 0.02 \\
\hline \multicolumn{4}{|c|}{$\mathrm{R}_{0} \pm$ S.D13.39 \pm 1.10} & \multicolumn{3}{|c|}{$3.54 \pm 0.54$} & \multicolumn{3}{|c|}{$2.17 \pm 0.45$} & \multicolumn{3}{|c|}{$2.49 \pm 0.46$} & \multicolumn{3}{|c|}{$2.21 \pm 0.46$} \\
\hline \multicolumn{4}{|c|}{ Reduction (\%) of $\mathrm{R}_{0}$} & \multicolumn{3}{|c|}{73.5} & \multicolumn{3}{|c|}{83.8} & \multicolumn{3}{|c|}{81.4} & \multicolumn{3}{|c|}{83.5} \\
\hline
\end{tabular}




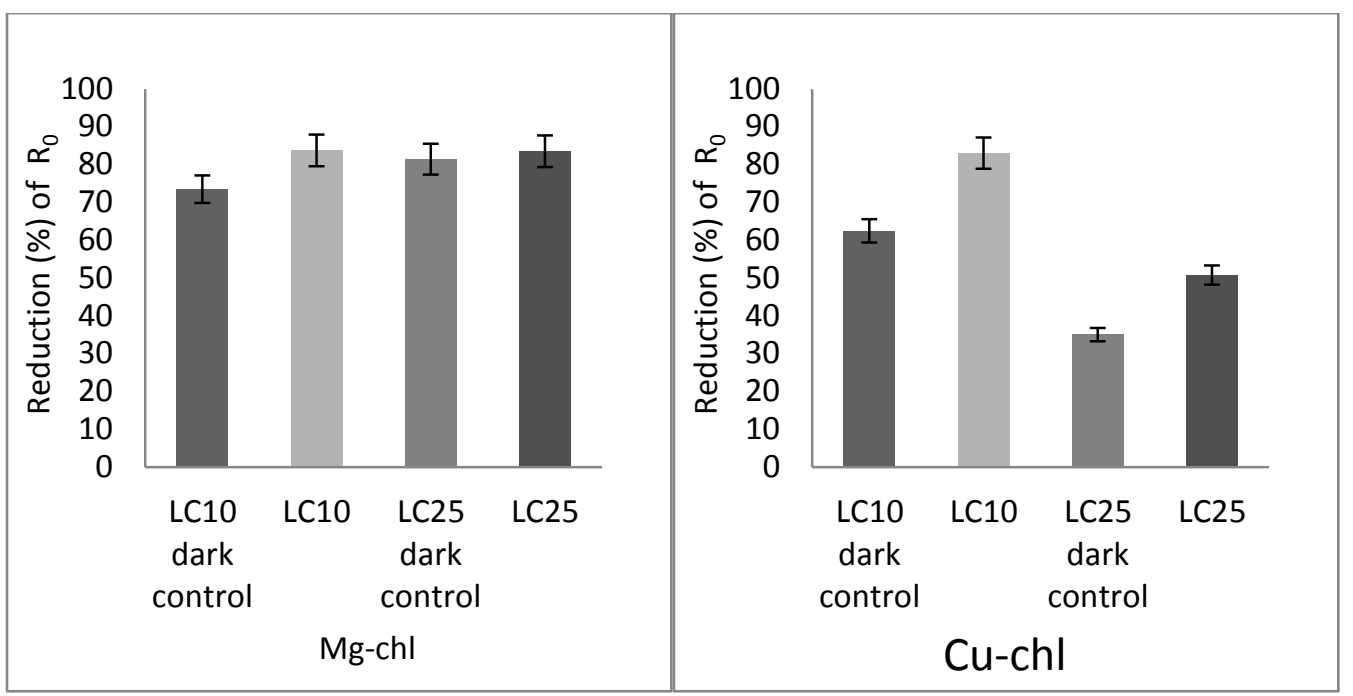

Fig (1) Reduction (mean \% \pm S.D) of reproductive rate $\left(\mathbf{R}_{0}\right)$ of Bulinus truncatus snails incubated in the dark with copper chlorophyllin ( $\mathrm{Cu}-\mathrm{chl})$ and magnesium chlorophyllin (Mg-chl), then exposed to light followed by eight weeks of recovery.

The values of reproductive rate $\left(\mathrm{R}_{0}\right)$ of treated snails were less than that of light control group, reflecting the reduction in their Lx and Mx values compared to those of the control snails (Fig 1). The reduction rates in $\mathrm{R}_{0}$ of snails at $\mathrm{LC}_{25} \mathrm{Cu}$-chl and $\mathrm{Mg}$-chl were $50.8 \%$ and $83.5 \%$, respectively.

Table (4) revealed an increase in total protein levels in snails' tissues incubated with $\mathrm{LC}_{50} \mathrm{Cu}$-chl, recording $108.1 \mathrm{mg} / \mathrm{g}$ tissue compared to $44.3 \mathrm{mg} / \mathrm{g}$ tissue of light control group $(\mathrm{p}<0.01)$. On the other hand, the snails incubated with $\mathrm{LC}_{90} \mathrm{Cu}$ chl suffered from significant reduction in their protein level $(21.3 \mathrm{mg} / \mathrm{g}$ tissue $)$ in comparison with that of light control snails $(\mathrm{p}<0.01)$. It was noticed, also, that the pattern of deteriorations in globulin and albumin levels of snails incubated with $\mathrm{Cu}$ chl was approximately similar to that of protein concentrations of these snail groups. Moreover, the levels of total protein, globulin and albumin of the snail groups incubated with $\mathrm{Mg}$-chl were significantly less than those of light control group $(\mathrm{p}<0.01)$. The levels of total protein of snails incubated at $\mathrm{LC}_{50}$ and $\mathrm{LC}_{90} \mathrm{Mg}$-chl were $20.2 \& 27.3 \mathrm{mg} / \mathrm{g}$ tissue, respectively, compared to $44.3 \mathrm{mg} / \mathrm{g}$ tissue of light control snails.

Concerning the activities of the enzymes AST, ALT and ALKP (Table 4), it was noticed that incubation of snails with $\mathrm{LC}_{50} \mathrm{Cu}$-chl significantly reduced AST activity, while it was increased by incubation with $\mathrm{LC}_{90}$ in comparison with the values of light control group. Similar observation was recorded with snails incubated with $\mathrm{LC}_{50}$ and $\mathrm{LC}_{90}$ of $\mathrm{Mg}$-chl. The activities of AST for snails incubated with $\mathrm{LC}_{90}$ of $\mathrm{Cu}$ chl and $\mathrm{Mg}$-chl were 23.3 and $59.4 \mathrm{U} / \mathrm{g}$ tissue, respectively, compared to $19.3 \mathrm{U} / \mathrm{g}$ tissue for light control group ( $\mathrm{p}<0.01)$. For the activity of AKP, incubation of snails with $\mathrm{Mg}$-chl significantly raised it in comparison with light control group, but generally, it was not significantly deteriorated by $\mathrm{Cu}$-chl treatment, except in snail group incubated in dark with $\mathrm{LC}_{90}$. The $\mathrm{AKP}$ activity for snails at $\mathrm{LC}_{90} \mathrm{Mg}$-chl was 12.5 U/g tissue compared to $4.7 \mathrm{U} / \mathrm{g}$ tissue for light control group $(\mathrm{p}<0.01)$. 
Table (4): Effect of copper chlorophyllin (Cu-chl) \& magnesium chlorophyllin (Mg-chl) on biochemical parameters of Bulinus truncatus snails.

\begin{tabular}{|c|c|c|c|c|c|c|}
\hline Treatment & $\begin{array}{c}\text { AST U/g } \\
\text { tissue }\end{array}$ & $\begin{array}{l}\text { ALT U/g } \\
\text { tissue }\end{array}$ & $\begin{array}{c}\text { AKP U/g } \\
\text { tissue }\end{array}$ & $\begin{array}{l}\text { Total Protein } \\
\mathrm{mg} / \mathrm{g} \text { tissue }\end{array}$ & $\begin{array}{c}\text { Albumin } \\
\mathrm{mg} / \mathrm{g} \text { tissue }\end{array}$ & $\begin{array}{c}\text { Globulin } \\
\mathrm{mg} / \mathrm{g} \text { tissue }\end{array}$ \\
\hline Light/control & $19.32 \pm 0.44$ & $10.26 \pm 0.11$ & $4.7 \pm 0.36$ & $44.3 \pm 0.31$ & $14.8 \pm 0.25$ & $29.5 \pm 0.25$ \\
\hline $\begin{array}{l}\text { Cu-chl } \mathrm{LC}_{50} \\
\text { dark control }\end{array}$ & $16.32 \pm 0,44 * *$ & $10.42 \pm 0.08$ & $4.1 \pm 0.25$ & $98.5 \pm 0.44 * *$ & $39.6 \pm 0.36^{* *}$ & $58.9 \pm 0.63 * *$ \\
\hline Cu-chl LC $\mathrm{LC}_{50}$ & $16.25 \pm 0.36^{* *}$ & $10.48 \pm 0.14$ & $4.44 \pm 0.08$ & $108.1 \pm 0.44 * *$ & $45.2 \pm 0.1 * *$ & $62.8 \pm 0.44 * *$ \\
\hline $\begin{array}{l}\mathrm{Cu}-\mathrm{chl} \mathrm{LC}_{90} \\
\text { dark control }\end{array}$ & $16.44 \pm 0.08 * *$ & $10.64 \pm 0.08$ & $11.63 \pm 0.11 * *$ & $44.6 \pm 0.25^{* *}$ & $25.0 \pm 0.25^{* *}$ & $19.6 \pm 0.44 * *$ \\
\hline $\mathrm{Cu}-\mathrm{chl} \mathrm{LC}_{90}$ & $23.3 \pm 0.25^{* *}$ & $15.42 \pm 0.11 * *$ & $4.36 \pm 0.08$ & $21.3 \pm 0.36^{* *}$ & $3.8 \pm 0.25 * *$ & $17.5 \pm 0.25 * *$ \\
\hline $\begin{array}{l}\mathrm{Mg} \text {-chl } \mathrm{LC}_{50} \\
\text { dark control }\end{array}$ & $16.26 \pm 0.11^{* *}$ & $10.42 \pm 0.11$ & $10.5 \pm 0.25 * *$ & $17.6 \pm 0.25^{* *}$ & $3.6 \pm 0.25 * *$ & $13.9 \pm 0.36 * *$ \\
\hline $\mathrm{Mg}$-chl LC $\mathrm{LC}_{50}$ & $16.52 \pm 0.14 * *$ & $12.3 \pm 0.25^{* *}$ & $5.9 \pm 0.25 * *$ & $20.2 \pm 0.36^{* *}$ & $6.9 \pm 0.44 * *$ & $13.3 \pm 0.38 * *$ \\
\hline $\begin{array}{l}\text { Mg-chl } L_{C_{90}} \\
\text { dark control }\end{array}$ & $23.34 \pm 0.11 * *$ & $12.6 \pm 0.25^{* *}$ & $11.36 \pm 0.08^{* *}$ & $23.8 \pm 0.25^{* *}$ & $6.9 \pm 0.57 * *$ & $16.9 \pm 0.36 * *$ \\
\hline Mg-chl LC 90 & $59.46 \pm 0.18 * *$ & $15.66 \pm 0.08 * *$ & $12.55 \pm 0.08^{* *}$ & $27.3 \pm 0.25^{*}$ & $8.5 \pm 0.36^{* *}$ & $18.8 \pm 0.44 * *$ \\
\hline
\end{tabular}
$* *=$ extremely significant, $(\mathrm{p}<0.001)$.

Examination of the hermaphrodite gland histological sections of control B.truncatus snails monitored numerous acini connected with a connective tissue (Fig. 2A). Each acinus lined with germinal epithelial cells and containing mature ova along its periphery in addition to developed sperms in its lumen.

The hermaphrodite gland transverse sections of snails treated with $\mathrm{LC}_{50}$ and $\mathrm{LC}_{90}$ of $\mathrm{Cu}-\mathrm{chl}$ and $\mathrm{Mg}$-chl (Fig. 2, B-G) revealed varying degrees of degenerations, atrophy and rupture of different cell types, ova and sperms of the glands' acini. Furthermore, the most prominent damages were clear in several vacuolated ova, degeneration and scattered sperms, as well as degeneration of the acinus' germinal epithelial layer that led to ceasing snails' oviposition for some weeks during the experimental period. 


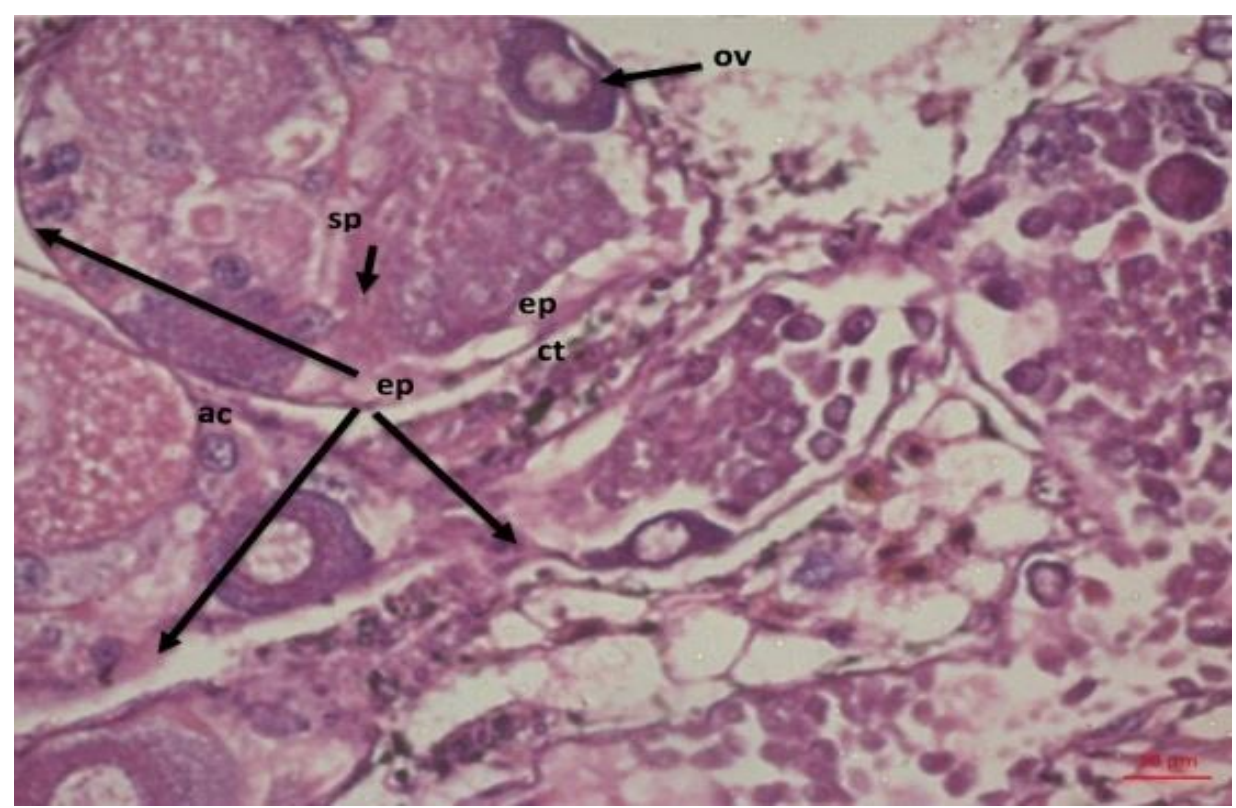

Fig (2) A- Light photomicrograph of a transverse section in the hermaphrodite gland of Bulinus truncatus (light control) stained with E\&H, exposed to light (desk lamp $100 \mathrm{~W} / 15 \mathrm{~cm}$ height) for 3 hours (x400). Showing: $\mathrm{Ov}=$ mature ova, $\mathrm{Sp}=$ developed sperms, Ac= compact acini, $\mathrm{Ct}=$ connective tissue, $\mathrm{Ep}=$ epithelial cells.

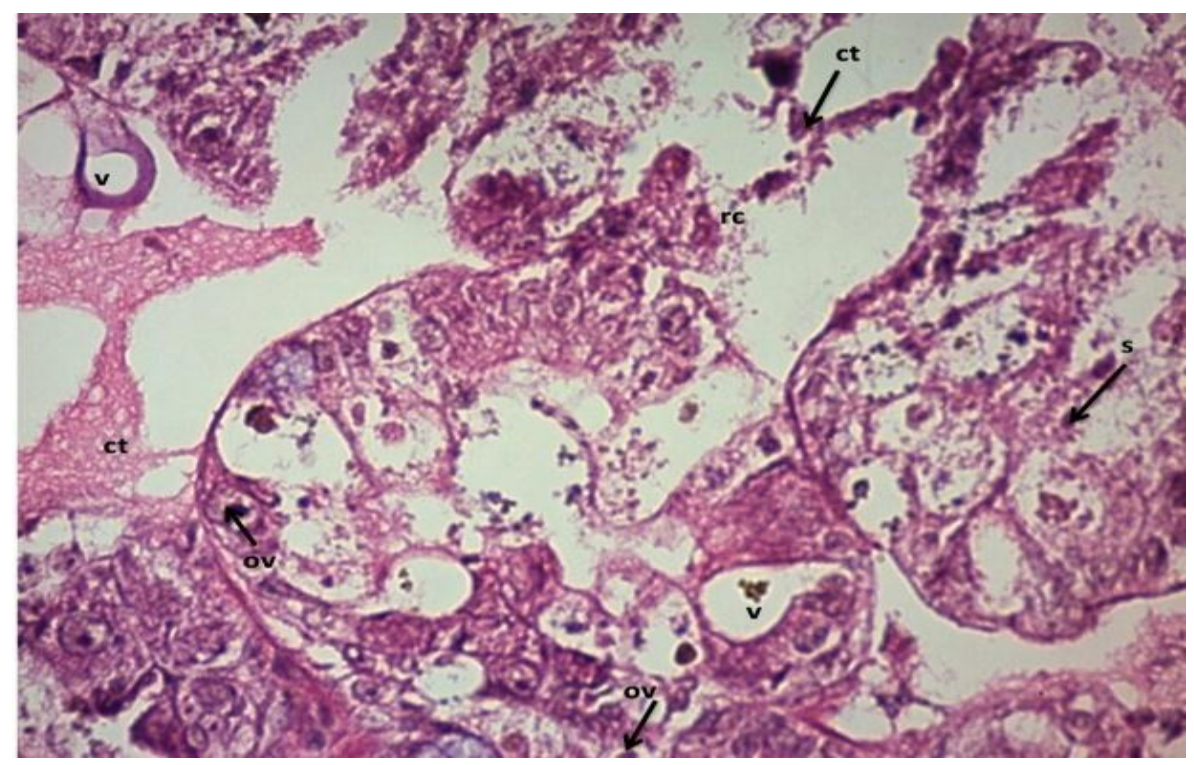

Fig 2: B- Light photomicrograph of hermaphrodite gland transverse section of $B$. truncatus snails treated LC50 Cu-chl and exposed to light, stained with E\&H (x400) showing: degenerated ova (ov), deformed sperms (s), rupture of acinus cells (Rc) with vacuoles (v), degeneration of connective tissue (ct). 


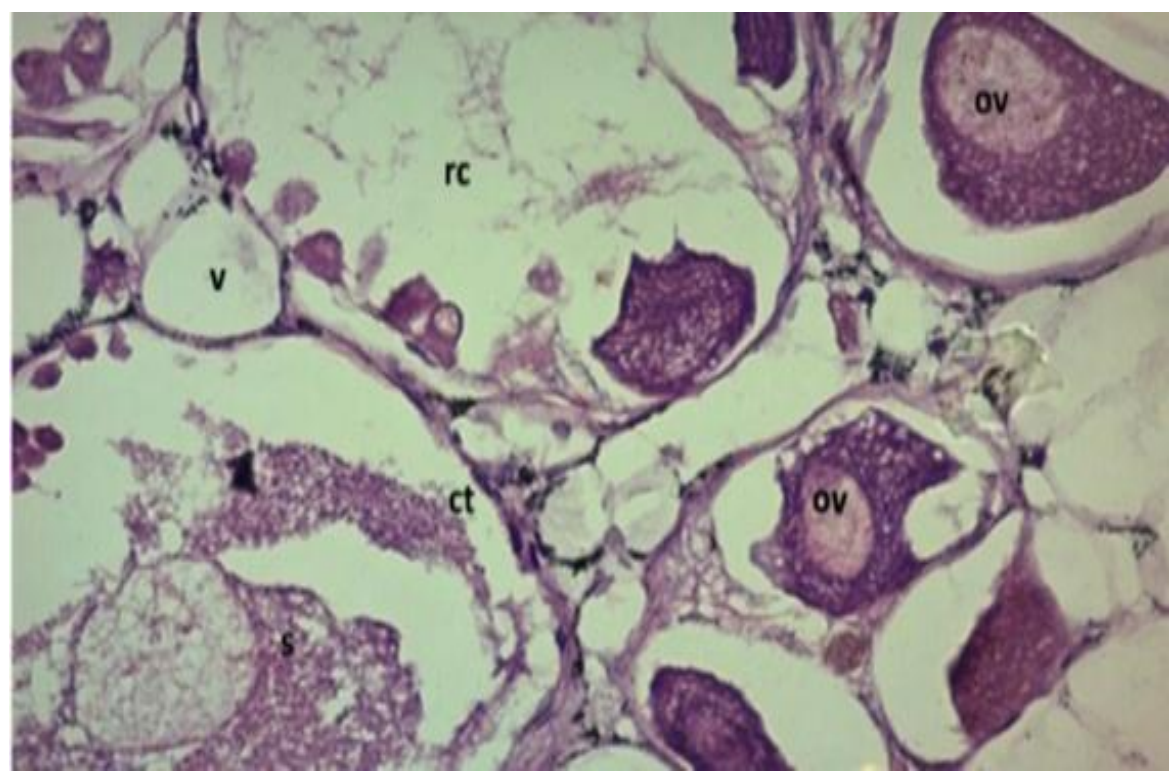

Fig 2: C-Light photomicrograph of hermaphrodite gland transverse section of B. truncatus snails treated LC90 Cu-chl and exposed to light, stained with E\&H (x400) showing rupture of cells and vacuoles in the acinus components, degeneration of connective tissue (ct) and ova (ov), damaged and irregular sperms (s).

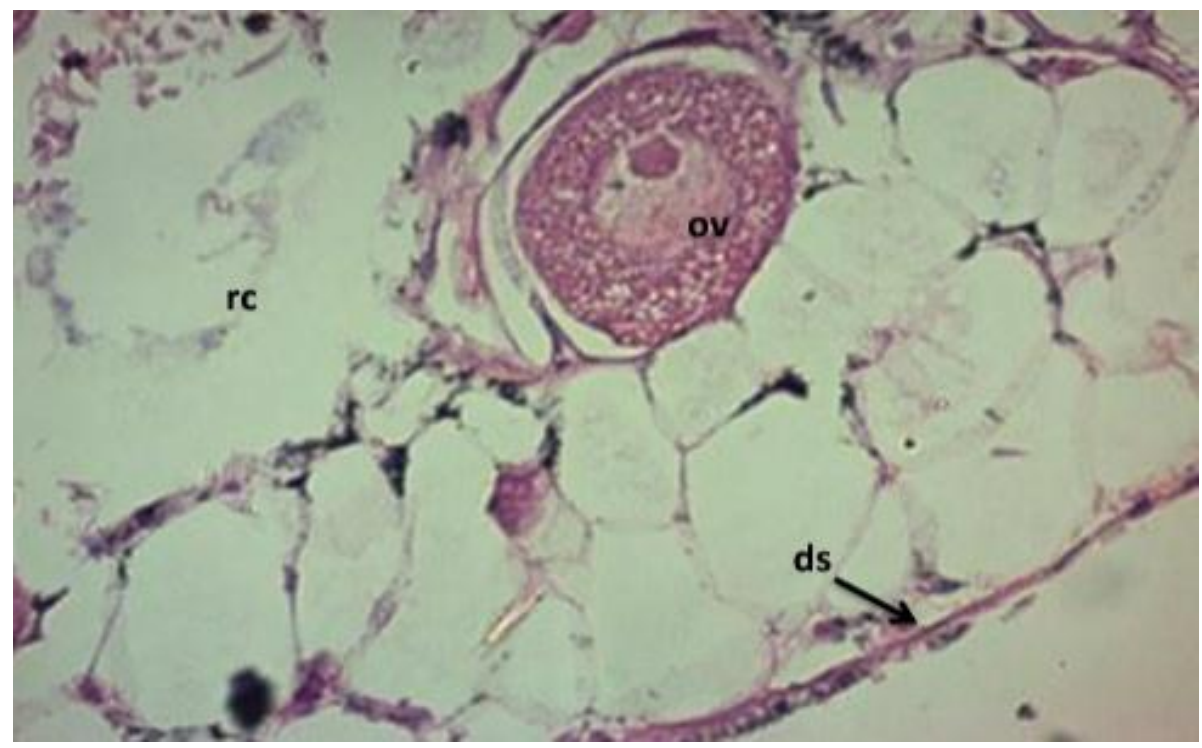

Fig2: D-Light photomicrograph of hermaphrodite gland transverse section of B. truncatus snails treated with $\mathrm{LC}_{90} \mathrm{Cu}$-chl in the dark (dark control), stained with $\mathrm{E} \& \mathrm{H}$ (x400), showing: vacuolated ova (ov), damage in developmental stages of spermatogenia (ds), rupture of acinus cells (rc). 


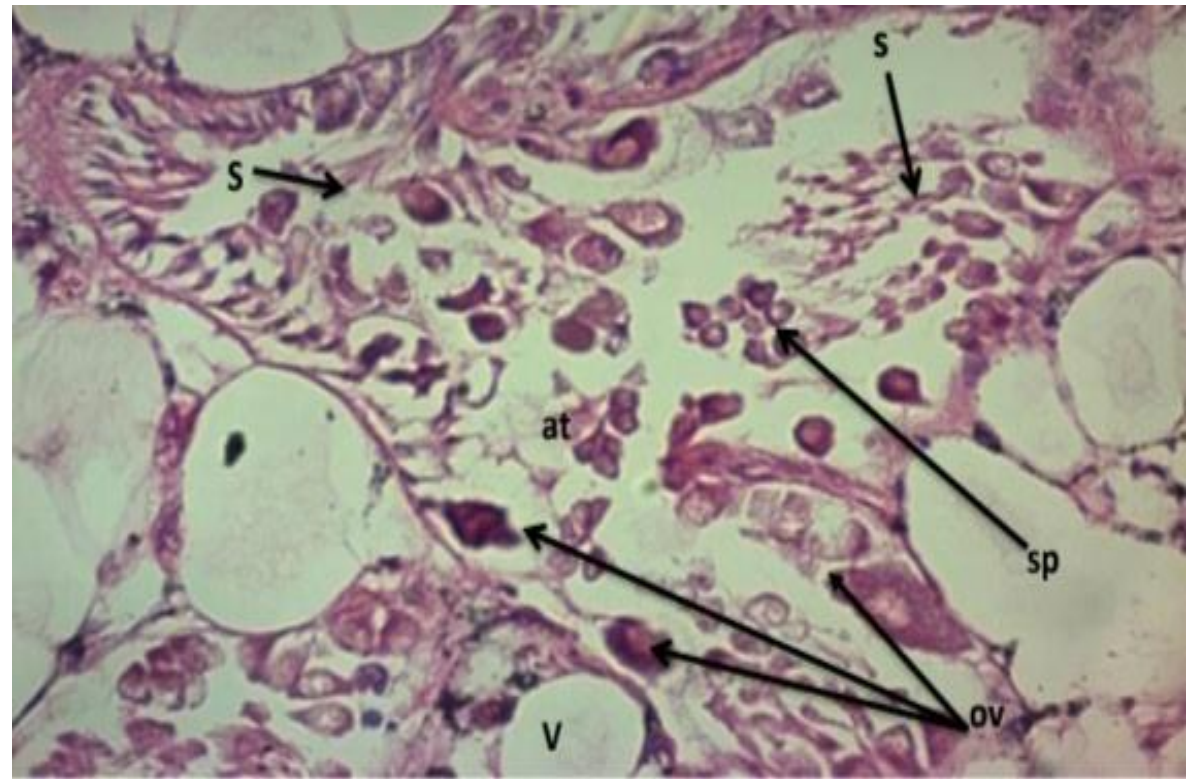

Fig 2: E-Light photomicrograph of hermaphrodite gland transverse section of B. truncatus snails treated withLC $\mathrm{C}_{50} \mathrm{Mg}$-chl and exposed to light, stained with $\mathrm{E} \& \mathrm{H}$ (x400) showing: degenerated spermatogonia (sp) and ova (ov), damaged sperms (s), atrophy and vacuoles in the acinus content (at).

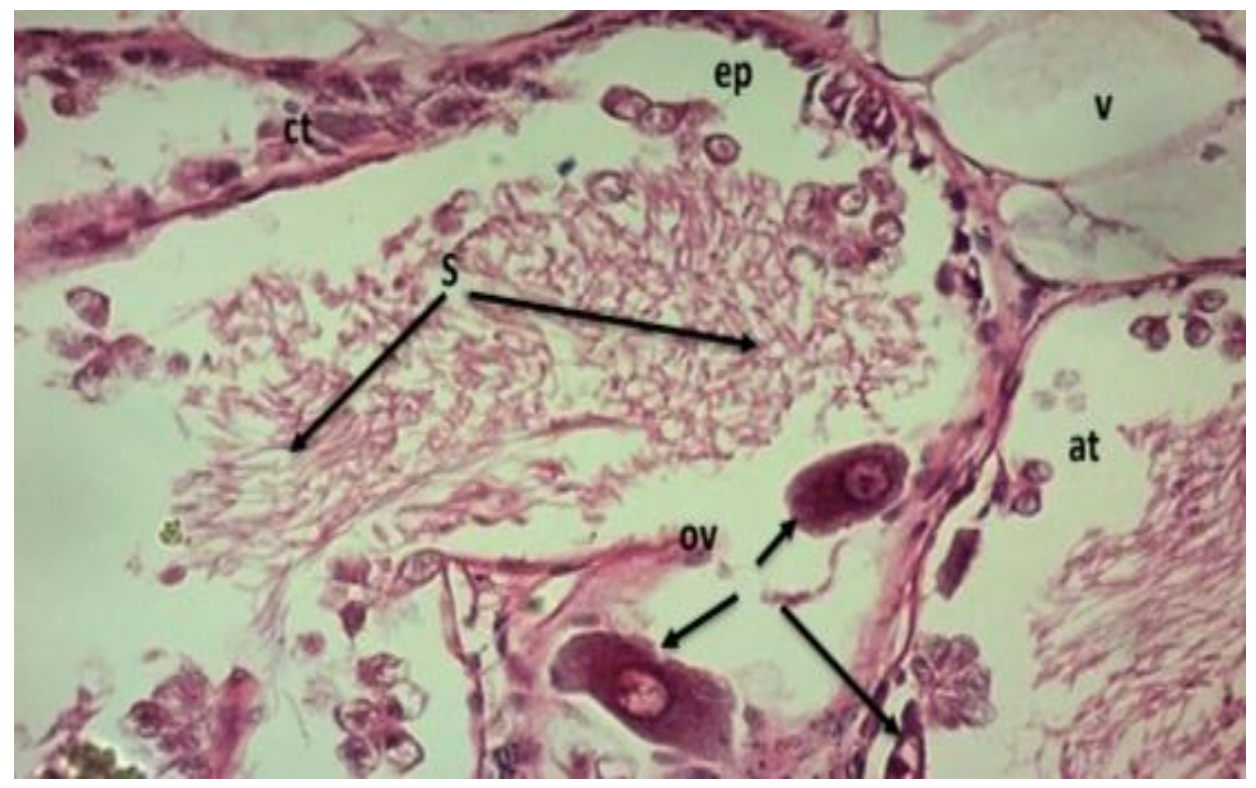

Fig 2: F- Light photomicrograph of hermaphrodite gland transverse section of B. truncatus snails treated with $\mathrm{LC}_{90} \mathrm{Mg}$-chl and exposed to light, stained with $\mathrm{E} \& \mathrm{H}$ (x400) showing: severe atrophy (at) in the acinus structure with vascular (v), scattered and irregular sperms (s), degenerated ova (ov), degeneration of connective tissue (ct) and epithelial cells (ep). 


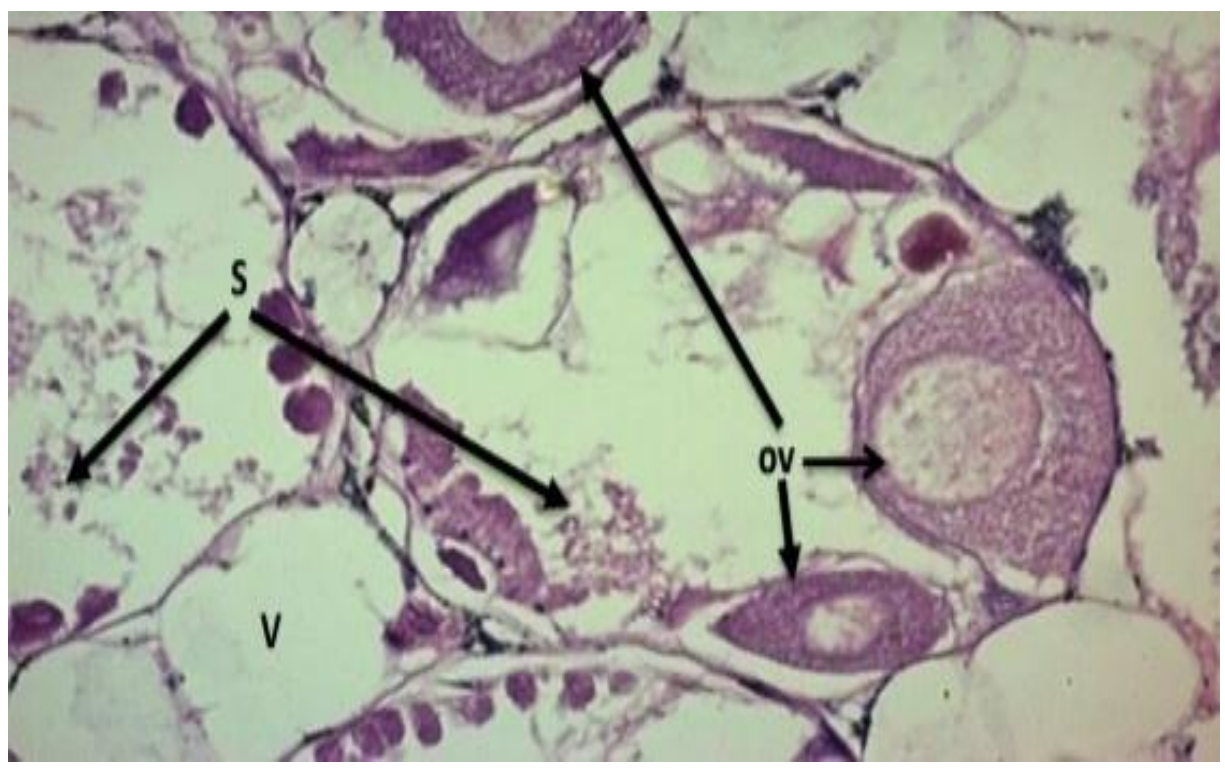

Fig 2: G- Light photomicrograph of hermaphrodite gland transverse section of B. truncatus snails treated with $\mathrm{LC}_{90} \mathrm{Mg}$-chl in the dark (dark control), stained with $\mathrm{E} \& \mathrm{H}$ (x400) showing: deleterious effects in acinus structure with vacuoles (v), vacuolated ova (ov), atrophy and degenerated sperms (s).

\section{DISCUSSION}

The control method would be more efficient and economically valuable in case of selecting to treat the available molluscicide for the particular habitat of snails. The current study determined that $\mathrm{Mg}$-chl was more toxic to $B$. truncatus snails than $\mathrm{Cu}$ chl, a result that agrees with the data of Ragheb et al (2013) on the toxicity of $\mathrm{Cu}$-chl and $\mathrm{Mg}$-chl to B. alexandrina snails. This could be due to the fact that $\mathrm{Cu}$-chl has a lower photo-reactivity than Mg-chl (Erzinger et al, 2011).

The survivorship (Lx) of B. truncatus snails after incubation with $\mathrm{Cu}$-chl and $\mathrm{Mg}$-chl, exposure to light and 8 weeks of recovery, was time and concentration dependent. Similar observations were noticed for $B$. alexandrina after exposure to the plants Collistimon citrinus and Zingiber officinale (EL-Emam et al, 2017) and Haplophyllum tuberculatum (Rizk et al, 2012). Moreover, the survival rate of nymphs of the milkweed bug (Spilostethus pandurus) was decreased with increasing the concentration of the photosensitizer hematoporphyrin (Elelimy et al., 2016).

The fecundity $(\mathrm{Mx})$ and reproductive rate $\left(\mathrm{R}_{0}\right)$ of $B$. truncatus snail groups incubated with $\mathrm{Cu}$-chl and $\mathrm{Mg}$-chl, exposed to light and recovered for 8 weeks were significantly less than those of light control group. This could be partially due to their high mortality rates and long periods of ceasing egg-laying during the recovery period. In addition to the interruption of their physiological activities, confirmed by the deteriorations caused by the effect of tested compounds on total protein levels and the activities of enzymes AST, ALT and AKP in their tissues, the decrease or cessation of snails' egg-laying capacity $(\mathrm{Mx})$ and the net reproductive rate $\left(\mathrm{R}_{0}\right)$ could be figured out. 
The upper-mentioned observations coincided with the reduction in $\mathrm{Mx}$ and $\mathrm{R}_{0}$ of B. alexandrina snails post incubation with $\mathrm{Cu}-\mathrm{chl}$ and $\mathrm{Mg}$-chl (Ragheb et al., 2013). In their study, they attributed this condition to the harmful oxidative stress of those compounds on both the regulation of snails' oviposition and the disturbances of their sex hormones (progesterone, testosterone and estradiol) affecting their tissues. El-Ansary et al (2001) stated that disturbance of some enzymes in B. alexandrina snails treated with sub-lethal concentrations of molluscicides correlated with the reduction of their egg-laying capacity. In addition, Elelimy et al, (2016) noticed that the biological parameters of milkweed bug $S$. pandurus deteriorated through increasing nymphal mortality. They realized a decreasing number of deposited eggs and a reducing percentage of eggs hatchability in post incubation with photosensitizer hematoporphyrin and exposure to sunlight in the summer season.

The total protein concentrations in tissues of $B$. truncatus snails incubated with $\mathrm{Mg}$-chl and exposed to light were significantly reduced compared to light control group. This was, also recorded with the high concentration $\left(\mathrm{LC}_{90}\right)$ of $\mathrm{Cu}$-chl. These results were confirmed by previous studies relating these changes to disturbances in the internal organs' function of treated snails to compensate and overcome the toxic stress of such compounds; this phenomenon requires high energy that may stimulate protein catabolism (Morad 2005). The negative effect on protein levels in tissues of $B$. alexandrine and $B$. truncatus snails, post exposed to heavy metals was previously stated by Tolba et al, (1997).

The activities of the enzymes AST, ALT and AKP, as biomarkers, may provide more information on the molluscicide induced stress on molluscs. The present deteriorations in the activities of these enzymes in tissues of B. truncatus snails treated with $\mathrm{Cu}$-chl and $\mathrm{Mg}$-chl may be due to the destructive stress of such compounds on hepatic tissues and/or the snails' trials to restore the amino acid balance in their body organs. This conclusion was previously recorded by EL-Emam and Ebeid (1989) in their study on B. alexandrina snails treated with mollotox. The high activities recorded for AST and ALT in B. truncatus treated with $\mathrm{LC}_{90} \mathrm{Mg}$-chl agreed with the data of Ragheb et al (2013) on B. alexandrina incubated with Mg-chl and exposed to light. Furthermore, the activities of AST and ALT were altered in hemolymph and tissues of Helisoma duryi and Lynenaea natalensis snails by low concentrations of copper, therefore they could be used as biomarker for water pollution (Masola et al, 2003).

The histological results of $B$. truncatus snails treated with $\mathrm{Cu}-\mathrm{chl}$ and $\mathrm{Mg}$-chl revealed marked destruction and degeneration of the hermaphrodite gland acini, spematogonia and oogonia, in addition to a disintegration of the acini connective tissue. The genital organs of treated snails may be sensitive to these sensitizers which could lead to minimizeor cease their oviposition. This support the present records on ceasing the snails'oviposition for some weeks upon exposure to these sensitizers that was mirrored on reduction of the snails'reproductive rate $\left(\mathrm{R}_{0}\right)$. These results were previously stated by Ragheb et al (2013) on destruction of the hermaphrodite and 
digestive glands cells of $B$. alexandrina snails treated with $\mathrm{Cu}$-chl and $\mathrm{Mg}$-chl and added that this might be due to the harmful effects exerted by such agents during the photosensitization process. Later on, in 2019, Ibrahim and Bakry stated that chlorophyllin extracted from deep-frozen leaves of Moringa oleifera plant exerted deleterious effects in the digestive gland of $B$. alexandrina snails treated with $\mathrm{LC}_{25}$ of water soluble chlorophyllin, represented by deformation of secretory cells, disintegration of the digestive cells and rupturing the connective tissue between the gland tubules. Moreover, Elelimy et al (2016) recorded that light and electron microscopic studies on mid-gut regions of the milkweed bug S. pandurus adults resulting from nymphs treated with the photosensitizer hematoporphyrin revealed severe disintegration of cells, many vacuoles, disappearance of most cell organelles and rupturing or detaching of nuclear membrane with clumping of its chromatin material.

The foregoing data revealed considerable molluscicidal activity of the photosensitizers $\mathrm{Cu}$-chl and $\mathrm{Mg}$-chl against B. truncatus snails. Moreover, these agents are capable of inducing significant deleterious effects on biochemical parameters of the treated snails and on their hermaphrodite gland tissues that was negatively reflected on their fecundity and reproductive rate. These harmful effects will greatly suppress the population size of the snail intermediate host of $S$. haematobium which could disturb and minimize schistosomiasis transmission. In addition, these photosensitizers are inexpensive and environmentally friendly. Therefore, they should be considered in the integrated control program of schistosomiasis to overcome the dangerous drawback of chemical molluscicides.

\section{REFERENCES}

Abdel-Hamid, H. and Mckawey, A.A. (2014). Biological and hematological response of Biomphalaria alexandrina to myco-biosynthsis silver nanoparticles. J. Egypt Soc. Parasitol., 44(3): 627-37.

Abdel Kader, M.H. and El-Tayeb, T.A. (2012). Field implementation using chlorophyll derivatives with sunlight for malaria,filaria and dengue fever vectors control in infested Africa swamps. Malaria J., 11 (Suppl 1):p 42.

Awad, H.H.; EL-Tayeb, T.A.; Abd EL-Aziz, N.M. and Abdel-Kader, M.H. (2008). A semi-field study on the effect of novel hematoporphyrin formula on the control of Culexpipiens larvae. J. Agricultural and Soc. Sci., 4(2): 85-88.

Bakry, F.A. (2009). Impact of some plant extracts on histological structure and protein patterns of Biomphalaria alexandrina snails. Global. J. Molec. Sci., 4(1): 34-41.

Bessey, W.A.; Lowry, O.H. and Brock, M.J. (1946). A method for the rapid determination of alkaline phosphatase with five cubic millimeters of serum.

J. Biol. Chem., 164: 321-329. 
Doumas, B.T. (1975). Standards for total serum protein assays: a collaborative study. Clin. Chem., 21:1159-1166.

El-Ansary, A.; Sammour, E.M.; Soliman, M.S. and Gawish, F.A. (2001). In vivo attenuation of schistosome cercarial development and disturbance of egglaying capacity Biomphalaria alexandrina using sub-lethal concentrations of plant molluscides. J. Egypt. Soc. Parasitol., 31 (30): 657-669.

Elelimy, H.A.S.; Awad, H.H. and Al-Tayeb, T.A. (2016). Effect of a novel photopesticide on some biological aspects of milkweed bug Spilostethus pandurus (Scopoli), with reference to ultrastructure changes in midgut. African Entomolgy, 24(1): 100-111.

El-Emam, M.A.; Osman, G.Y.; Abdel Hamid, H.; Mohamed, A.M. and Ali,R.E.M. (2017). Determination of egg-laying capacity, sex hormones and mortality of Biomphalaria alexandrina snails exposed to methanol extract from curcumin and the plants Callistemon citrenus and Zingiber officinale. J.Bio. Sci. Appl. Res., 3:97-109.

El-Emam, M. A. and Ebied, F.A. (1989). Effect of Schistosoma mansoni infection, starvation and molluscicides on acid phosphate, transaminases and total protein in tissues and hemolymph of Biomphalaria alexandrina. J. Egypt. Soc. Parasitol., 19: 139-147.

El-Emam, M.A.; Gawish. F.A.;Habib, M.R.; Wang, W.; Le-Ping,S.; Engels, D.; Zhang, N.M.;Jia, T.W. and Zhou,X.N. (2020). Semi-field and field trials to control Biomphalaria alexandrina and Bulinus truncatus intermediate host snails of schistosomasis in Egypt by the plant molluscicide Luowei/TDS 4\%. Egypt. J. aquatic Boil. \&Fish., 24 (5): 95-109.

El-Nahas, H.A. and El-Deeb, F.A. (2007). Molluscicidal potency of Pittosporum tobira vearigatum and Hedera canariensis plants against juvenile and adult Biomphalaria alexandrina snails. J. Egypt Aquatic Biol. \& Fish, 11(1):151170.

Erzinger, G. S.; Wohllebe, S.; Vollrath. F.; Souza, S. C.; Richter, P.; Lebert, M. and Häder, D. P.(2011). Optimizing conditions for the use of chlorophyll derivatives for photodynamic control of parasites in aquatic ecosystems. Parasitol Res., DOI 10.1007/s00436-011-2322-7.

Finney, D.J. (1970). Probit analysis ( $3^{\text {rd }}$ ed..). Cambridge University Press.

Gustafsson J (1976). Improved specificity of serum albumin determination and estimation of Bacute phase reactants by use of the bromcresol green reaction. Clin. Chem., 22:616-622.

Ibrahim, A.M. and Bakry, F.A. (2019). Assessment of the molluscicidal impact of extracted chlorophyllin on some biochemical parameters in the nervous tissue and histological changes in Biomphalaria alexandrina and Lymnaea natalensis snails. Invertebrate Neuroscience, 19:1-7. 
Ibrahim, A. M.; EL-Emam, M.A.; EL-Dafrawy, S.M. and Mossalem, H.S. (2004). Impact of certain plant species on Schistosoma mansoni-Biomphalaria alexandrina system. Proc. 3rd Int. Conf. Biol. Sci. Tanta University 3-4 Apr.,pp.390-413.

Kavita,Singh, D.K.; Vinay, Singh; Kumar Singh (2017). Chlorophyllin treatment against the snail Lymnaea acuminata: A new tool in fascioliasis control. Pharmacogn J. 2017, 9(5):594-598.

Luksiene, Z. (2005). Photosensitization: An overview, new approach to inactivation harmful and pathogenic microorganisms by photosensitization. Food Technol. Biotechnol., 43 (4): 411-418.

Masola, B.M.; Chibi, Y.S.; Naik, E. and Zaranyika, M.F. (2003). Activities of glutamate dehydrogenase and aspartate and alanine aminotransferase in fresh water snails Helisoma duryi and lymnaea natalensis exposed to copper. Biomarkers, 8(1): 33-42.

Morad, E.M.N. (2005). Comparative study on the molluscicidal activity of some plant extracts on snail vector of Schistosoma mansoni, $\backslash$ Biomphalaria alexandrina. $\mathrm{Ph}$. D. thesis Fac. Sci. Cairo. Univ., Egypt. Mossalem et al (2013) stated the antimalarial agent artemether has molluscicidal effect against Biomphalaria alexandrina snails.

Mossalem, H. S.; Abdel-Hamid, H. and El-Shinnawy, N.A. (2013). Impact of artemether on some histological and histochemical parameters in Biomphalaria alexandrina, African Journal of Pharmacy and Pharmacology, 7: 2220-2230.

Perrett, S. and Whitfield, P.J. (1996). Currently available molluscicides. Parasitol, Today 12: 156-159, https://doi. org/10.1016/0169.4758(96) 1000 1-6.

Ragheb, M.; EL-Tayeb, T.;El-Emam, M.;Amer, M. and Bashtar, A. (2013). Copper chlorophyllin and magnesium chlorophyllin as molluscicidal agents against Biomphalaria alexandrina snails. Asian Acad. Res. J. Multi-Discipl., 23192801.

Reitman, S. and Frankel, S. (1957). Acolorimetric method for the determination of serum glutamic oxalacetic and glutamic pyruvic transaminases. Am J Clin. Pathol., 28:56-63.

Rizk, M.; Metwally, N.; Hamed, M.; and Mohamed, A. (2012). Correlation between steroid sex hormones, egg laying capacity and cercarial shedding in Biomphalaria alexandrina snails after treatment with Haploplhyllum tuberculatum. Exp. Parasitol. 132: 171-179.

Sokal, R.R. and Rohlf, F.J. (1995). Introduction to Biostatistics. W.H. Freeman and Co., San Francisco, pp: 271- 273. 
Steinmann, P.; Keiser,J.; Bos, R.; Tanner,M. and Utzinger, J. (2006). Schistosomiasis and water resources development, systematic review, meta-analysis and estimates of people at risk. Lancet Infect. Dis. 6:411-425.

Tolba, M.R.; Mohamed, B. and Mohamed, M. (1997). Effect of some heavy metals on respiration, mean enzyme activity and total protein of the pulmonate snails Biomphalaria alexandrina and Bulinus truncatus. J. Egypt. Germ. Soc. Zool., 24 (D): 17-32.

WHO (1965). Molluscicide screening and evaluation. Bull. WHO, 33: 567-581.

WHO (1993).The control of schistosomiasis. 2nd Report of WHO Expert Committee, Technical Report Series No 830:1-86. 